\title{
THE ROLE OF TREE DOMESTICATION IN GREEN MARKET PRODUCT VALUE CHAIN DEVELOPMENT IN AFRICA
}

\author{
Patrick Van Damme \\ Department of Plants and Crops, Ghent University, Belgium \\ Current president of the Ghent Africa Platform (GAP)
}

\begin{abstract}
Internationally, there is increasing interest in acquiring 'green' market, organic and/or fair trade products, also sourced from the wild. The latter is expected to come from well-managed (forest) systems. This has led to the development and implementation of programmes designed to reduce deforestation and forest degradation (for mitigation of climate change, and sustainable provision of environmental goods and services) (REDD and REDD+). Crucially, this approach needs to be extended to the many poor, hungry and marginalized smallholder farmers in developing countries so that they can benefit from this increased market interest, but also to allow them to improve their natural resource (management) basis. In this context, agroforestry tree domestication has made considerable progress in the last 20 years, especially in Africa, in providing planting materials of many new tree crops for food, cosmetic and pharmaceutical industries and consumer markets across many agro-ecological zones. Tree domestication is an important element and the first necessary step in the development of sustainable tree production for introduction in agroforestry systems. These trees can then form the basis of Non-Timber Forest Production (NTFP) that can feed into livelihood development. In contrast to wild trees, planted trees can offer a more regular and continuous supply of NTFPs that then feed into local-to-global value chains and highly sophisticated markets that demand higher quality and greater uniformity. Together with research institutes, local farmers are now developing new, more performant cultivars of species of interest. They thus eventually help to create direct benefits from the processing and subsequent marketing of food and non-food products in local, regional and international markets. The latter activities also create business and employment opportunities in local cottage industries. Similarly, through the indirect environmental and ecological services provided by trees, food security can be greatly enhanced as agroforestry may improve the production environment of crops and thus close the yield gap (i.e. the difference between the potential and actual yield) of modern crop varieties. In this way, agroforestry adds income generation to agro-ecological approaches which together reverse the cycle of land degradation and social deprivation whilst at the same time transforming the lives of poor farmers. However, these benefits do not come without some risks: the loss of genetic diversity and local rights over genetic resources, and exploitation by unscrupulous entrepreneurs. Agroforestry developments should therefore focus on better access to 'green' business opportunities for poor smallholder farmers in Africa by maximizing the benefits and minimizing the risks.
\end{abstract}

KEYWORDS: AGROFORESTRY TREE PRODUCTS; GENETIC DIVERSITY; INDIGENOUS TREE SPECIES; LIVELIHOODS, REDD+ 


\section{Introduction}

Agroforestry tree domestication, especially as pursued by the World Agroforestry Centre (ICRAF), is now entering its third decade. In the last 20 years, great progress was made as documented by Leakey et al. (2012). Advances were on two distinct levels. In a first stage, domestication consisted of a phase of field and laboratory research performed by formal research institutes, where new strategies and techniques were tested and developed, whereas the biology and genetics of target tree species were also studied in order to provide a better understanding of the potential for genetic selection to meet many different and new domestic and more international market opportunities (Leakey \& Akinnifesi 2008; Leakey et al. 2012). In effect, this first phase was rather top-down. In a second phase, this whole domestication approach was implemented as a (more beneficiary-driven and thus) participatory process in which local communities are helped by so-called Rural Resource Centres to engage and innovate in ways that ensure that they are the beneficiaries and owners of their own initiatives, the latter consisting of planting useful tree species and integrating them in their farming systems (Tchoundjeu et al. 2010; Asaah et al. 20II; Leakey 20I2c).

In Africa, in particular, where most of the traditional agricultural production systems integrate trees, animals and crops, and where most of the latter is small-scale, focusing on the tree component is of primordial importance. Hence this review on the role of tree domestication in small-farmer livelihood development.

Through the domestication and cultivation of little known wild trees producing common-property, Non-Timber Forest Products (NTFPs) are transformed into agricultural crops producing AgroForestry Tree Products (AFTPs) (Leakey 2012b). The domestication process involves steps to (I) evaluate the ethnobotanical and socio-economic potential of the wild resource of useful species, (2) characterize and quantify the extent of genetic variation, (3) effectively capture and make salient use of genetic variation, and finally (4) determine how best to integrate the domesticates within a wide range of farming systems for greater social, economic and environmental benefits (Leakey 20I2a).

More specifically, the domestication of indigenous tree species that produce traditionally and culturally important products ultimately leads to the introduction of these perennials in low-input agroforestry systems where they produce foods, medicines and other goods which are marketable in niche markets that are socially, economically and environmentally sustainable. These sustainably produced AFTPs and their associate environmental/ ecological services can therefore be seen as contributing to 'green' markets that comprise:

- organic and locally grown food;

— 'health' and 'natural personal care' products;

— sustainably produced building materials (e.g. timber);

- complementary, alternative and preventive medicine (naturopathy, Chinese and Ayurvedic medicine, etc.); while also contributing to

- 'fair trade', eco-certification and sustainable eco-tourism.

Recognizing the merits and pull effect of 'demand-side economics' (Dixon \& Richards, 20I6), targeting and 'using' local, regional and international markets for AFTPs is vital for promoting successful adoption of agroforestry and agroforestry species on a suf- 
ficiently large scale to have a meaningful economic, social and environmental impact. Importantly, making high quality germplasm available to farmers opens the way for the development of new niche markets, thus creating opportunities for rural communities to enter the cash economy.

Agricultural policies have traditionally (and erroneously) set their primary focus on promoting the supply side. However, it is important to ensure that supply does not exceed demand. Producers should also be aware of market expectations, especially in terms of the quality and timely delivery of products. Therefore, market expansion for organic ATFP foods will only be effective if the institutional set-up is adequate and enabling, and encompasses policy networks including organic farmers' associations, certification agencies and public authorities; and if it includes/is based on the provision of well-informed and -targeted R\&D as well as educational efforts (know-how).

Ecosystem services markets ${ }^{I}$ encompass a wide range of practices, such as watershed protection, the conservation and/or sustainable use of threatened species, etc. Currently, however, there is great interest in reducing measurable and verifiable greenhouse gas emissions and development of carbon markets, through a number of financial mechanisms, such as Reduction in Deforestation and Forest Degradation (REDD), and the conservation and sustainable management of forests and the enhancement of forest carbon stocks (REDD+) (Moe \& Rottereng, 20I8). REDD consists of a set of steps designed to use market and financial incentives in order to reduce (or avoid) the emission of greenhouse gases, while REDD ${ }^{+}$fosters improved forest management that helps reduce deforestation and enhances forest carbon stocks. The latter mechanisms can both be promoted through the introduction and adoption of agroforestry. Both REDD and in particular $\mathrm{REDD}^{+}$operate in novel market environments which generate funding. They involve mechanisms that both combat climate change and improve human wellbeing in developing nations. Consequently, they represent a suite of policies, institutional reforms and programmes that provide monetary incentives for developing countries to reduce greenhouse gas emissions and sustain economic growth by halting or preventing the destruction of forests. ${ }^{2}$

Agroforestry offers the potential to add tree-based REDD/REDD ${ }^{+}$income generation to product marketing. In order to foster the latter, agroforestry embraces a holistic approach to rural development (Leakey \& Asaah 2013). This process starts with the prioritization of the most important species through preference ranking exercises with key stakeholders and using ethnobotany as a source of use-information (Van Damme \& Kindt 20II). This is followed by farmer-led identification and characterization of superior germplasm, and progresses through participatory tree domestication, to tree planting and sale of AFTPs (Leakey 20I2a).

Generally speaking, many plants and animals have been domesticated by humankind through successive generations of selection and breeding. However, in the case of trees,

I http://www.green-markets.org/context.htm

2 http://www.conservation.org/learn/climate/solutions/mitigation/pages/climate_redd.aspx 
the conventional crop breeding approach takes a long time and gains are small in each generation. This is because of the long period from seed germination to the attainment of sexual maturity, and the out-breeding nature of trees that results in genetic segregation during sexual reproduction. Fortunately, however, plants are amenable to asexual regeneration which means that it is possible to produce multiple copies of a selected individual plant by rooting stem cuttings, or by grafting, budding or marcotting (air layering) techniques (Leakey 2004). Using these relatively simple techniques, it is possible to rapidly capture and multiply selected individuals as clones or cultivars (cultivated varieties). While these techniques have been known and used for thousands of years, they have only recently been applied to tropical and subtropical tree species that for many centuries have provided local people with traditionally important foods, medicines and other products for everyday use through gathering from wild tree stands. The success of these asexual regeneration techniques has highlighted the potential and also been the start of agroforestry tree domestication (Leakey 2012a).

From the outset a key element of the strategy used in this (basically ICRAF-led) domestication programme, has been to ask local, often resource-poor, farmers which species they would have liked to domesticate and what characteristics they would have liked to improve (Tchoundjeu et al. 2010; Asaah et al. 20II). In response to the first question (which species to domesticate), the majority of farmers, especially in Africa, have said that they would like to domesticate local fruit and nut species which are nutritionally important and which have local (and sometimes regional) markets (see supra for the two-phase approach showing where farmers participate in the domestication process). Regarding the second question (what characteristics to focus on), a common response is that they prefer earlier fruiting (shorter time to sexual maturation) and plants of short stature that facilitate ease of harvesting. Fortunately, both outcomes are easy to achieve when using vegetative propagation techniques by propagating material from the already mature crown of selected tree specimens that have the required or expected characteristics. Indeed, through vegetative propagation, one preserves the mother trees' features, whereas production of plants from seeds is less unambiguous as in many cases the 'father' is not known especially with cross-pollinating species.

Similarly, vegetative propagation techniques also make it easy to meet the needs of new and traditional, commercial markets for uniformity, quality and regularity of supply-characteristics which enhance the market price charged to the consumer, but also the prices that can be obtained by producers. Uniformity and quality are a direct response to and derive from clonal propagation, whereas regularity of supply should be the outcome of large-scale propagation of cultivars. The achievement of these targets is of great importance to maximizing the outcomes of the AFTP value chain, as these characteristics are of increasing importance with each successive step along the value chain: from local to global (Figure I), and also for meeting the expectations of green and niche markets. One of the specificities of agroforestry systems is that they build on and use symbiotic natural equilibria and mutualistic relationships to counter both abiotic and biotic stresses, and to make the most of environment and natural (soil) resources. Agroforests that 
make no use of external (chemical) inputs are production options appropriate to and form an integral part of green marketing, but are also highly beneficial as approaches to sustainable intensification of tropical agriculture as they generate income, boost food and nutritional security; restore and maintain aboveground and below-ground biodiversity, as well as corridors between protected forests; serve as $\mathrm{CH}_{4}$ sinks; maintain watershed hydrology; promote soil conservation (Pandey 2002), as well as having social benefits such as greater security over land tenure, enhanced gender equity and employment/ business opportunities (Leakey 2013). Agroforests also mitigate demand for wood and reduce pressure on natural forests. Promotion of the woodcarving industry facilitates long-term carbon sequestration in artefacts whereas it also brings about new sequestration through intensified tree growth (following increased demand for these objects that basically 'have' to come from specific species). The potential delivery of all these benefits means that there is an urgent need to support the integration of agroforestry approaches to tropical agriculture through the development of suitable policies. This can be assisted by, and based on, robust country- and continent-wide scientific studies aimed at better understanding the potential of agroforestry and ethnoforestry for climate change mitigation and human well-being.

\section{The domestication-commercialization continuum}

a value chain usually starts with a producer who can ensure that the quality of the raw product sold at the 'farm gate' is as high (and uniform) as possible. This runs counter to the natural heterogeneity of products from wild tree populations. Many studies of treeto-tree variation in a range of marketable AFTPs (fruits, nuts, kernel oils, food thickening agents, pharmaceuticals, perfumed essential oils and so on) have exhibited 3- to ro-fold variations in types and quality of end products (Van Damme et al., I999; Atangana et al. 200I; Anegbeh et al. 2003; Waruhiu et al. 2004; Leakey et al. 2005a, 2005b, 2005c, 2008; Assogbadjo et al. 2006; Scheldeman et al., 2007; Page et al. 20I0; Abasse et al. 20II; Atangana et al. 20II).

Interestingly, and as illustrated by the continuous nature of this intraspecific variation, there has been no strict indication of specific varieties within these AFTP populations (Leakey et al. 20I2). Furthermore, it is only recently that work formally describing and characterizing specific ideotypes, or the so-called 'plus' germplasm, has been done (Leakey \& Page 2006). However, the variability which, for example, is seen in any bulk load of fruits, is one of the major reasons why wholesale traders pay low prices to farmers, even though retail markets recognize this variability and charge customers more for the better (bigger and tastier) fruits (Leakey et al. 2002; De Caluwé et al. 2010a, 20Iob; De Caluwé 20II). The market logic is such that it is not until traders can buy bulk loads of a standard quality (i.e. of a single cultivar) that there is the prospect of farmers receiving a better price for their 'farm gate' sales. ${ }^{3}$ This can be seen in products such as apples, pears, plums, etc., sold in shops and supermarkets in industrialized countries, 
but is also increasingly the case for lesser-known, so-called neglected and underutilized species such as cherimoya (Annona cherimola) as shown by the Cumbe case in Peru (Vanhove \& Van Damme 2013). The latter authors found that value chain features such as market channels, chain governance, quality performance and the distribution of added value over the component links in the chain differ significantly between cherimoya fruits that are traditionally produced and marketed, versus those that are registered by a collective trademark, such as the 'Cumbe' variety. The latter is exported from its production area (Lima province in Peru) to neighbouring Andean countries, as graded and highly selected fruits with greater quality. This creates significant value for both producers and traders, while the former local (and traditional) cherimoyas have lower value due to their uneven and unpredictable quality. Studies on the genetic diversity of cherimoya in the countries of origin have stressed the necessity for conserving highly diverse (southern Ecuador and northern Peru) or rare (Bolivia) cherimoya germplasm as sources of within-species genetic (bio)diversity for broadening the breeding basis.

There are some concerns that commercial success of superior cultivars may lead to a loss of genetic diversity, which is understood as loss of variation in crops due to the modernization of agriculture (van de Wouw et al. 2009), and may occur when farmers who believe that quality is exclusively linked to a certain genotype purchase or exchange grafts from/between each other. Potentially, this is a risk, but currently the evidence suggests that this risk may not be as great as feared, as the possible concomitant genetic erosion has been minimal in species such as apples and grapes which have been cultivated and traded for hundreds of years (Gross \& Miller 20I4). In cutnut (Barringtonia procera), indigenous to the Pacific, more than $70 \%$ of the tree-to-tree variation in the Solomon Islands was found to occur at the level of a village population (Pauku et al. 2010). This is similar to high person-to-person variation seen in people at the village/town level, although genetic variability also includes elements attributable to specific races, tribes and families; in people we are familiar with the recognition of elite individuals as sporting heroes, beauty queens, Nobel Prize winners, Oscar winners, etc. In crops, similar recognition can be accorded to individual plants that meet the specific expectations or needs of a particular market due to their particular combination of a number of specific genetic traits - an ideotype (Leakey \& Page 2006). To understand all these variations, studies have been conducted on a number of agroforestry trees to evaluate multi-trait variation using characterization web diagrams (Atangana et al. 2002; Leakey 2005; Simbo et al. 2013). To appreciate the potential, Leakey (2012a) has likened these opportunities to those captured by dog breeders from the genetic diversity of the wolf (von Holdt et al. 2012).

With regard to the risk of genetic erosion, the current approach in participatory domestication of agroforestry trees results in a number of cultivars of each species in each participating community. This means that the diversity in unselected traits will remain high across the production population of each species. This conclusion is supported by the findings from molecular studies of Barringtonia procera (Pauku et al. 2010) and Adansonia digitata (Assogbadjo et al. 2006) showing that trees with particular morphotypes are 
not necessarily closely related. It would thus seem that the risk of genetic erosion is small, provided a wise domestication strategy is followed (Leakey \& Akinnifesi 2008). There are already over 50 agroforestry tree species under some level of domestication (Leakey et al. 2012) and potentially hundreds, if not thousands, more could be domesticated in this way. As many tree species produce more than one useful or marketable product (e.g. Garcinia kola; Leakey 2012a; or Vitex doniana; Dadjo et al. 2012), it is also possible to identify a number of different trait combinations (e.g. fruit or nut ideotypes) within a single species, and sometimes within a particular product (e.g. oils for food, cosmetics and medicinal products from a nut). Thus, kernel oils with different chemical components or physical traits may have potential in pharmaceutical, cosmetic or food industries, leading to a hierarchy of ideotype selections (Leakey 20I2a). Taking all this inter- and intra-specific diversity into account, the potential scale of the value chains emanating from the domestication of agroforestry trees is enormous and offers scope for new industries to dramatically change the economies of tropical societies and nations (Leakey I999).

ICRAF's agroforestry tree domestication programme has now become global and is implemented in Africa, Latin America, Asia and Oceania. It thus represents a new wave of crop domestication, focused on improving the livelihoods of farmers and the national economies of developing countries in general, and these of Africa in particular (Leakey 20I2c; Leakey \& Asaah 2013). Another potential risk arising from successful domestication, however, is that unscrupulous entrepreneurs seeing the market potential of domesticated cultivars with marked quality characteristics will try to circumvent or undermine the initiatives of poor rural communities engaged in tree domestication (Leakey \& Izac I996). To try to minimize this risk, Lombard and Leakey (2010) have proposed the development of a register of farmer-derived cultivars, with a GPS location for the mother tree and a DNA 'fingerprint' of the clone. The need to match supply (tree domestication and cultivation) with demand (tree product commercialization) means that domestication initiatives need to be matched with marketing initiatives all along the value chain from the local to the global scales. Currently, the domestication initiatives in agroforestry are mostly at a local scale. Consequently, much focus is on the development of cottage industries conditioning, drying and packaging tree products for local and some regional markets (Asaah et al. 20II; Leakey \& Asaah 2013). These initiatives are aimed at moving the place of many tree products from the traditional street markets towards new business opportunities. This process involves trying to engage local community members as new entrepreneurs and initiate small- and medium-scale enterprises, thereby creating employment in value-addition and associated activities, such as the local fabrication of simple processing equipment (Leakey \& Asaah 2013; Mbosso et al. 2015).

However, in addition, there are also some marketing initiatives that are running ahead of domestication, in which the trade in processed tree products to regional and international markets has preceded domestication. These initiatives face the risk that demand may be restricted by low quality, lack of uniformity and unreliable supply. At the global level, there is also a small number of commercial initiatives involving tree products. These are 
Public-Private Partnerships in which multinational companies are working directly with local communities in developing countries (Leakey 20I2a). One of these involves Unilever plc. and communities in Ghana, Nigeria and Tanzania that are domesticating Allanblackia spp. as a new oil crop for margarine production (Jamnadass et al. 2010) on account of its unique fatty acid content which displays considerable tree-to-tree variation in oleic and stearic acid composition (Atangana et al. 20II; Tsobeng et al. 20I6).

\section{Towards sustainable and multifunctional agriculture}

it has recently been suggested that agroforestry can be used to close the so-called yield gap (i.e. the difference between the potential yield of modern crop varieties and the yield actually achieved by poor smallholder farmers in the tropics and sub-tropics; Leakey 20I2a, 2012b). Indeed, in a well-managed agroforestry systems, trees are seen as complementing crop production, not as competing with them.

This could be achieved by a three-step process involving: (i) the restoration of soil fertility and the rehabilitation of agro-ecological functions of the production environment; (ii) tree domestication; and (iii) the commercialization of agroforestry tree products. Moreover, it is recognised that in this way agroforestry is capable of improving food and nutritional security, poverty alleviation and rehabilitation of degraded land so that new areas of forest do not need to be cleared for the expansion of agriculture to feed the growing human population. In other words, agroforestry can deliver Multifunctional Agriculture, in which outputs are the enhanced production of crops and livestock in ways that are environmentally, socially and economically much more sustainable than those from conventional farming practices (Leakey 2012a, 2012b). Seen from this perspective, the role of tree domestication in value chain development takes on very high priority in the rural development of tropical and subtropical countries.

\section{Towards a resilient green market for agroforesty tree products and agroforestry systems}

developing good-quality germplasm material for a broad range of green markets is one thing. However, making these markets function is another. REDD and similar approaches to marketing for reduced carbon and greenhouse gas emission are becoming increasingly global, and are being promoted by national governments and international organizations. As such, $\mathrm{REDD}^{+}$can act as an incentive to plant more trees as it compensates/ rewards farmers and farmer organisations who do so. At local levels, however, there is some scepticism and dissent based on the fact that very often REDD/REDD ${ }^{+}$-like systems often lead to the inequitable delivery of benefits to the wrong stakeholders. Nevertheless, the general thrust of current negotiations is towards increasing acceptance by producer groups, and the improvement of current compensation schemes that involve most or all of the stakeholders. To avoid the kind of negative outcomes seen in earlier reforestation schemes, REDD ${ }^{+}$must incorporate the following: rights-based spatial planning; equitable and accountable distribution of financial incentives; improved financial governance to prevent corruption and fraud; policy reform to remove perverse incentives for forest 
conversion; and the strengthening of economic benefits and safeguards for smallholders, e.g. such as the use of multi-purpose tree species (Barr \& Sayer 2012).

As mentioned earlier, AFTPs occurring in resource-poor farming systems are by default - for socio-economic reasons - generally organic, and thus well-fitted for introduction into green and fair trade markets. There are, however, a number of elements that may constrain sustainable ATFP market development. These, for example, are the inadequacy of transportation facilities, communication systems, financial capital or access to credit, market information and linkages, and limited knowledge about ATFP market and market information among households. The latter is limited, rendered deficient and significantly influenced by socio-economic factors such as household members' education, gender, income level and ethnicity, and the distance to market and road access.

However, local AFTP markets can offer many inspiring and motivating advantages. Local markets exist and may be relatively large, while export markets often have to be developed ex nihilo. Local markets are relatively stable and guaranteed, while export markets are often fickle, unstable and frequently demonstrate 'boom and bust' characteristics. Participants in local markets are often independent, whereas export markets may suffer from dependencies which increase the risk of the loss of benefit to poor producers and the collapse of demand if any of the actors withdraw. Another problem can be the sophisticated requirements of export markets for levels of processing, quality control and grading that are beyond the capacities of local producers. By comparison, local markets are relatively unregulated and involve less bureaucracy. In addition, the lower value of goods sold in local markets poses a lower risk of take-over by wealthy businessmen or displacement by large-scale, capital-intensive producers. All told, therefore, local markets have lower entry barriers compared to export markets, as there is a minimal requirement for intervention and capital investment to support local trade and enhance livelihood benefits. This allows poor, unskilled and marginalized community members to engage in - and learn - the trade.

The cultural value of many local and traditionally traded products also provides market stability and can be used to expand markets amongst urban communities with strong rural roots. Many of these products have value in local markets which may be unknown in export markets which tend to be socially and geographically foreign. In addition, local market dynamics are adapted to the situations of remote areas where supply and demand are in better balance as production, and thus offer, usually responds to concrete local demand patterns. Participation in these local markets may also give producers greater control, as they can set their own prices, sell where and to whom they wish, and determine their own work pace to fit in with other household activities. Local producers and traders therefore understand the needs of the market and its quality standards and expectations. Last but not least, local markets are accessible and close to producers/traders thus reducing transaction costs relative to export markets (Shackleton et al. 2007).

However, there are some disadvantages to local markets. For example, they may show limited potential for growth or grow more slowly than export markets and can quickly become saturated. This limits the opportunities for new entrants and can thus constrain 
the expansion of individual businesses and hence limit income generation. Local markets may also have poor external visibility and so are often neglected by policy makers and development planners. Low visibility can also result in inadequate research and development support (e.g. extending shelf life, resource ecology and management) relative to emerging internationally marketed products. Other constraints can include a lack of technology, credit, contacts or skills needed to develop business opportunities. Rural areas may have scant access to market intelligence and may be beholden to historical trade patterns with less potential for product diversification to reduce risk of market collapse in the long run. Producers supplying these local markets are often dispersed over large areas making it difficult to target interventions and build collaboration. In these areas, informal traders may face problems establishing themselves in the market place and frequently encounter harassment; furthermore, the conditions under which they operate are often poor.

In conclusion, producers supplying local markets may be constrained from performing all or most functions along the trade chain (Shackleton et al. 2007). Nevertheless, the horizontal integration of a value chain offers opportunities for more control, the realization of more benefits and lower levels of dependency. At the same time, consumers located near local markets are often poor and have limited purchasing power keeping prices low. Products in specialized export markets can often fetch high prices. There may be few buyers in local markets for producers who are creative and produce high quality, unusual goods. Local markets are often located in marginalized areas characterized by poorly developed transport and communication.

Given all these potential benefits, but also in the face of the constraints faced by the commercialization of AFTPs, there is a need to raise the status of local and national AFTP trade. Shackleton et al. (2007) suggest that this can be done by:

- integrating tree products into national surveys for statistical documentation of volumes and values generated by agricultural and forest goods, and into household income and expenditure surveys;

- communicating trade statistics to increase awareness of the size, value and significance of the trade amongst key stakeholders such as traditional authorities, local government structures and municipalities, conservation agencies, forestry officials, retailers, consumers and the general public;

- seeking political backing for the local and national trade in important indigenous products;

- raising the status of collectors/producers/extractors and remove associated stigmas;

- recognizing, affirming and facilitating development based on existing/traditional knowledge;

- identifying and supporting cultural links to forest products;

— promoting locally produced products through, e.g., special markets, fairs, etc.;

- facilitating multi-stakeholder fora to support development of AFTP markets;

- seeking to integrate AFTPs with other development sectors to form part of a holistic approach to development and poverty alleviation - AFTPs on their own are often limited in their potential for livelihood support and other forms of income generation are also necessary. 


\section{Conclusion}

In conclusion, important strides are being taken in agroforestry to initiate integrated rural development approaches which transform many tree-based food and non-food products, which were formerly harvested from the wild, into new sophisticated market commodities for local, regional and sometimes even international markets. Furthermore, this is being done in ways which also improve the sustainability of tropical agriculture by reversing the complex set of interacting environmental, social and economic factors which cause the downward spiral of land degradation and social deprivation that traps millions of farmers in poverty, malnutrition and hunger. By focusing on all the links in the value chain, this approach is also creating opportunities for poor rural communities to get onto the bottom rungs of the ladder into the cash economy by creating opportunities for the development of cottage industries and the service industries which support them. This approach also opens up the opportunity to benefit from payments for environmental services, such as carbon markets and the environmental and social product certification schemes, that flow from more environmentally and socially sustainable agriculture.

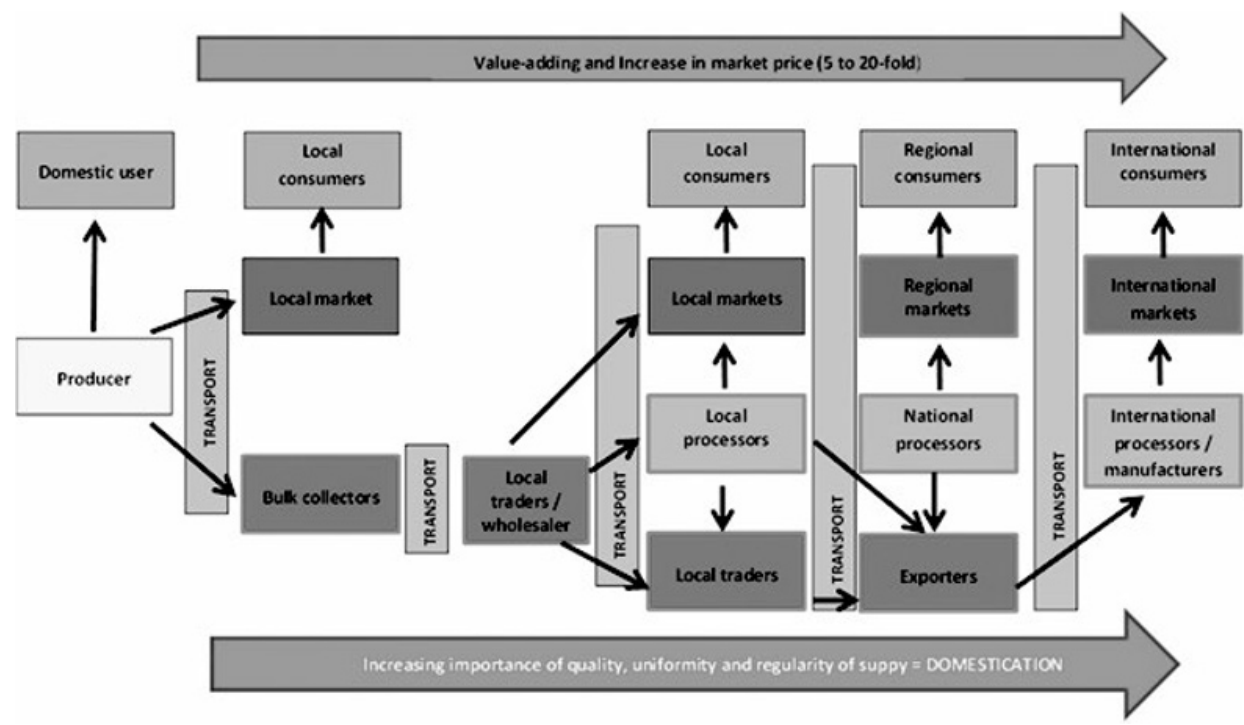

Figure 1: Domestication and the value chain: domestication becomes increasingly important with each step from local to global because of the increasing need for product uniformity, quality and regularity of supply - criteria which are associated with increasing market price. 


\section{References}

Abasse T, Weber JC, Katkore B, Boureima M, Larwanou M, Kalinganire A. 20Ir. Morphological variation in Balanites aegyptiaca fruits and seeds within and among parkland agroforests in eastern Niger. Agroforestry Systems, 8I: 57 -66.

Anegbeh PO, Usoro C, Ukafor V, Tchoundjeu Z, Leakey RRB, Schreckenberg K. 2003. Domestication of Irvingia gabonensis: 3. Phenotypic variation of fruits and kernels in a Nigerian village. Agroforestry Systems, 58: 213-2I8.

Asaah EK, Tchoundjeu Z, Leakey RRB, Takoutsing B, Njong J, Edang I. 20II. Trees, agroforestry and multifunctional agriculture in Cameroon. Int J Agric Sustain. 9:IIO- IIg.

Assogbadjo AE, Kyndt T, Sinsin B, Gheysen G, Van Damme P. 2006. Patterns of genetic and morphometric diversity in baobab (Adansonia digitata L.) populations across different climatic zones in Benin (West Africa). Ann Bot. 97:819-830.

Atangana AR, Tchoundjeu Z, Fondoun J-M, Asaah E, Ndoumbe M, Leakey RRB. 200I. Domestication of Irvingia gabonensis: I. Phenotypic variation in fruit and kernels in two populations from Cameroon. Agrofor Syst. 53:55- 64 .

Atangana AR, Ukafor V, Anegbeh PO, Asaah E, Tchoundjeu Z, Usoro C, Fondoun J-M, Ndoumbe M, Leakey RRB. 2002. Domestication of Irvingia gabonensis: 2 . The Selection of multiple traits for potential cultivars from Cameroon and Nigeria. Agrofor Syst. 55:22I - 229.

Atangana AR, van der Vlis E, Khasa DP, van Houten D, Beaulieu J, Hendrickx H. 20Ir. Tree-to-tree variation in stearic and oleic acid content in seed fat from Allanblackia floribunda from wild stands: potential for tree breeding. Food Chem. I26:1579-1585.

Barr CM, Sayer JA. 2012. The political economy of reforestation and forest restoration in AsiaPacific: critical issues for REDD . Biol Conserv. 154:9 - I9.

http://www.conservation.org/learn/climate/ solutions/mitigation/pages/climate_redd.aspx - accessed June 2018.

Dadjo C, Assogbadjo AE, Fandohan B, Glélé Kakaï R, Chakeredza S, Houehanou TD, Van Damme P, Sinsin B. 2012. Uses and management of black plum (Vitex doniana Sweet) in Southern Benin. Fruits. 67:239-248.

De Caluwé E. 20II. Market potential of underutilized plant species: the case of baobab (Adansonia digitata L.) and tamarind (Tamarindus indica L.) in Mali and Benin [PhD thesis]. Ghent: Ghent University, I88 pp.

De Caluwé E, Halamova' K, Van Damme P. 20roa. Adansonia digitata L. A review of traditional uses, phytochemistry and pharmacology. Afrika Focus. 23:II- 5I.

De Caluwé E, Halamova' K, van Damme P. 2orob. Tamarindus indica L. A review of traditional uses, phytochemistry and pharmacology. Afrika Focus. 23:53-83.

Gross B, Miller A. 20I4. From field to table: perspectives and potential for fruit domestication. In: Batello C, Cox S, Wade L, Pogna N, Bozzini A, Choptiany J, editors. Proceedings from the FAO expert workshop on perennial crops for food security. FAO: Rome.

Jamnadass R, Dawson IK, Anegbeh P, Asaah E, Atangana A, Cordeiro NJ, Hendrickx H, Henneh S, Kadu CAC, Kattah C, et al. 2010. Allanblackia, a new tree crop in Africa for the global food industry: market development, smallholder cultivation and biodiversity management. For Trees Livelihoods. I9:25I- 268 .

Dixon, J. \& Richards, C. (2016). On food security and alternative food networks: understanding and performing food security in the context of urban bias. Agriculture and Human Values, 33 (I), I9I-202.

http://www.green-markets.org/context.htm - accessed June 2018.

Leakey RRB. 1999. Potential for novel food products from agroforestry trees. Food Chemistry, 64:I -I4.

Leakey RRB. 2004. Physiology of vegetative reproduction. In: Burley J, Evans J, Youngquist JA, editors. Encyclopaedia of forest sciences. London: Academic Press; p. I655- I668. 
Leakey RRB. 2005. Domestication potential of Marula (Sclerocarya birrea subsp. caffra) in South Africa and Namibia: 3. Multi-trait selection. Agrofor Syst. 64:5I- 59 .

Leakey RRB. 2012a. Living with the trees of life: towards the transformation of tropical agriculture. Wallingford: CABI, $200 \mathrm{pp}$.

Leakey RRB. 20I2b. Non-timber forest products - a misnomer? Guest editorial. J Trop For Sci. 24:I45 $-\mathrm{I} 46$.

Leakey RRB. 2012c. Participatory domestication of indigenous fruit and nut trees: new crops for sustainable agriculture in developing countries. In: Gepts P, Famula TR, Bettinger RL, Brush SB, Damania AB, McGuire PE, Qualset CO, editors. Biodiversity in agriculture: domestication, evolution and sustainability. Cambridge: Cambridge University Press; p. 479-50I.

Leakey RRB. 2013. Addressing the causes of land degradation, food/nutritional insecurity and poverty: a new approach to agricultural intensification in the tropics and sub-tropics. In: Hoffman U, editor. Wake up before it is too late: make agriculture truly sustainable now for food security in a changing climate. UNCTAD Trade and Environment Review 2013. Geneva: UN Publications; p. $192-198$.

Leakey RRB, Akinnifesi FK. 2008. Towards a domestication strategy for indigenous fruit trees in the tropics. In: Akinnifesi FK, Leakey RRB, Ajayi OC, Sileshi G, Tchoundjeu Z, Matakala P, Kwesiga F, editors. Indigenous fruit trees in the tropics: domestication, utilization and commercialization. Wallingford: CAB International; p. $28-49$.

Leakey RRB, Asaah EK. 2013. Underutilised species as the backbone of multifunctional agriculture: the next wave of crop domestication. Acta Hortic. 979:293 - 310.

Leakey RRB, Atangana AR, Kengni E, Waruhiu AN, Usuro C, Anegbeh PO, Tchoundjeu Z. 2002. Domestication of Dacryodes edulis in West and Central Africa: characterisation of genetic variation. For Trees Livelihoods. I2 (Special Issue on Dacryodes edulis):57- 72.

Leakey RRB, Fuller S, Treloar T, Stevenson L, Hunter D, Nevenimo T, Binifa J, Moxon J. 2008. Characterization of tree-to-tree variation in morphological, nutritional and chemical properties of Canarium indicum nuts. Agrofor Syst. 73:77-87.

Leakey RRB, Greenwell P, Hall MN, Atangana AR, Usoro C, Anegbeh PO, Fondoun J-M, Tchoundjeu Z. 2005c. Domestication of Irvingia gabonensis: 4. Tree-to-tree variation in foodthickening properties and in fat and protein contents of Dika nut. Food Chem. 90:365-378.

Leakey RRB, Izac A-M. I996. Linkages between domestication and commercialization of nontimber forest products: implications for agroforestry. In: Leakey RRB, Temu AB, Melnyk M,editors. Domestication and commercialization of non-timber forest products. Non-Wood Forest Products No. 9. Rome: FAO; p. I -7 .

Leakey RRB, Page T. 2006. The 'ideotype concept' and its application to the selection of 'AFTP' cultivars. For Trees Livelihoods. I6:5- I6.

Leakey RRB, Pate K, Lombard C. 2005b. Domestication potential of Marula (Sclerocarya birrea subsp. caffra) in South Africa and Namibia: 2. Phenotypic variation in nut and kernel traits. Agrofor Syst. 64:37-49.

Leakey RRB, Shackleton S, du Plessis P. 2005a. Domestication potential of Marula (Sclerocarya birrea subsp. caffra) in South Africa and Namibia: I. Phenotypic variation in fruit traits. Agrofor Syst. 64:25-35.

Leakey RRB, Weber JC, Page T, Cornelius JP, Akinnifesi FK, Roshetko JM, Tchoundjeu Z, Jamnadass R. 2012. Tree domestication in agroforestry: progress in the second decade. In: Nair PK, Garrity D, editors. Agroforestry: the future of global land use. New York (NY): Springer; p. I45- I73.

Lombard C, Leakey RRB. 20Io. Protecting the rights of farmers and communities while securing long term market access for producers of non-timber forest products: experience in southern Africa. For Trees Livelihoods. 19:235 - 249. 
Mbosso, C., Degrande, A., Villamor, G.B., Van Damme, P., Tchoundjeu, Z. and Tsafack. S. (2015). Factors affecting the adoption of agricultural innovation: the case of a Ricinodendron heudelotii kernel extraction machine in southern Cameroon. Agroforestry Systems, 89 (5), 799 - 8II (doi: I0.1007/sio457-015-9813-y).

Moe, E. \& Rottereng, J.K.S. (20I8). The post-carbon society: Rethinking the international governance of negative emissions. Energy research and social science, 44:I99-208.

Page T, Southwell I, Russell M, Tate H, Tungon J, Sam C, Dickinson G, Robson K, Leakey RRB. 20 Io. Geographic and phenotypic variation in heartwood and essential oil characters in natural populations of Santalum austrocaledonicum in Vanuatu. Chem Biodivers. 7:1990 - 2006. Pandey DN. 2002. Carbon sequestration in agroforestry systems. Clim Policy, 2:367-377.

Pauku RL, Lowe A, Leakey RRB. 20I0. Domestication of indigenous fruit and nut trees for agroforestry in the Solomon Islands. For Trees Livelihoods, I9:269-287.

Scheldeman, X., Willemen, L., COPPENS D’EECKENBRUGGE, G., ROMEIJN-PEETERS, E., RESTROPO, M.T., ROMERO MOTOCHE, J., JIMENEZ, D., LOBO, M., MEDINA, C.I., REYES, C., RODRIGUEZ, D., OCAMPO, J.A., VAN DAMME, P. \& GOETGHEBUER, P. (2007). Distribution, diversity and environmental adaptation of highland papaya (Vasconcellea spp.) in tropical and subtropical America. In: HAWKSWORTH, D.L. \& BULL, A.T. (Eds.). Series Topics in Biodiversity and Conservation. Vol. 6. Plant Conservation and Biodiversity. Springer, Dordrecht. The Netherlands, p. 293-310.

Shackleton S, Shanley P, Ndoye O. 2007. Invisible but viable: recognizing localmarkets for nontimber forest products. Inter For Rev. 9:697 -7I2.

Simbo DJ, De Smedt S, Van den Bilcke N, De Meulenaer B, Van Camp J, Uytterhoeven V, Tack F, Samson R. 2013. Opportunities for domesticating the African baobab (Adansonia digitata L.): multi-trait fruit selection. Agrofor Syst. 87:493-505.

Tchoundjeu Z, Degrande A, Leakey RRB, Simons AJ, Nimino G, Kemajou E, Asaah E, Facheux C, Mbile P, Mbosso C, Sado T, Tsobeng A. 20Io. Impact of participatory tree domestication on farmer livelihoods in west and central Africa. For Trees Livelihoods. I9:219 -234.

Tsobeng, A. C., Ofori, D., Tchoundjeu, Z., Asaah, E. \& Van Damme, P. (2016). Improving growth of stockplants and rooting ability of leafy stem cuttings of Allanblackia floribunda Oliver (Clusiaceae) using different NPK fertilizers and periods of application. New Forests, 47 (2), I79 - I94 (doi: I0.1007/siro56-0I5-95I7-I).

Van Damme, V., Van Damme, P. \& Scheldeman, X. (Eds.) (I999). Proceedings of the First International Symposium on Cherimoya. Loja/Ecuador, March I6-I9, I999, 38I pp.

Van Damme P, Kindt R. 20II. Ethnobotanical methods. In: Dawson I, Harwood C, Jamnadass R, Beniest J, editors. Agroforestry tree domestication: a primer. Nairobi: ICRAF; p. 28 - 35 .

van de Wouw, M., Kik, C., van Hintum, T., van Treuren, R. and Visser, B. (2009). Genetic erosion in crops: concept, research results and challenges. Plant Genetic Resources, 8(I), I - I5 (https://doi.org/IO.IOI7/SI479262109990062).

Vanhove W, Van Damme P. 2013. On-farm conservation of cherimoya (Annona cherimola Mill.) germplasm diversity: a value chain perspective. Trop Conserv Sci. 6:I58- I8o.

Von Holdt BM, Gray MM, Wayne RK. 20I2. Genome-wide approaches for the study of dog domestication. In: Gepts P, Famula TR, Bettinger RL, Brush SB, Damania AB, McGuire PE, Qualset CO, editors. Biodiversity in agriculture: domestication, evolution and sustainability. Cambridge: Cambridge University Press; p. 275-298.

Waruhiu AN, Kengue J, Atangana AR, Tchoundjeu Z, Leakey RRB. 2004. Domestication of Dacryodes edulis: 2 . Phenotypic variation of fruit traits in 200 tress from four populations in the humid lowlands of Cameroon. Food Agric Environ. 2:340 - 346.

https://www.wfp.org/content/farm-gate-price-monitoring-impact-countries-lesson-learned-20I3-20I4pilot-april-20I6 - accessed 8 October 2018. 